\title{
Mutational Activation of the STE5 Gene Product Bypasses the Requirement for G Protein $\beta$ and $\gamma$ Subunits in the Yeast Pheromone Response Pathway
}

\author{
MIRIAM SARAH HASSON, ${ }^{1,2}+$ DMITRY BLINDER, ${ }^{1} \ddagger$ JEREMY THORNER, ${ }^{2}$ \\ AND DUANE D. JENNESS ${ }^{1 *}$ \\ Department of Molecular Genetics and Microbiology, University of Massachusetts Medical School, \\ Worcester, Massachusetts $01655{ }^{1}$ and Department of Molecular and Cell Biology,
} University of California, Berkeley, California $94720^{2}$

Received 10 September 1993/Returned for modification 13 October 1993/Accepted 6 November 1993

The STE5 gene encodes an essential element of the pheromone response pathway which is known to act either after the G subunit encoded by the STE4 gene or at the same step. Mutations in STE5, designated STE5 ${ }^{\text {Hyp }}$, that partially activate the pathway in the absence of pheromone were isolated. One allele $\left(S T E 5^{\text {Hyp }}{ }_{-2}\right)$ was shown to cause a single amino acid substitution near the $\mathbf{N}$ terminus of the predicted STE5 protein. Immunoblotting with anti-Ste5 antibodies indicated that the phenotype was not due to an increased level of the mutant STE5 protein. A multicopy episomal plasmid containing a $S T E 5^{H H p}$ allele partially suppressed both the block in pheromoneinducible transcription and the sterility phenotype caused by null alleles of the STE2, STE4, or STE18 gene, indicating that the $S T E 5$ product acts after the receptor (STE2 product) and after the $G$ protein $\beta$ and $\gamma$ subunits (STE4 and STE18 products, respectively). However, the phenotypes of the STE5 ${ }^{H y p}$ mutations were less pronounced in ste 4 and ste18 mutants, suggesting that the $S T E 5^{H y p}$-generated signal partially depends on the proposed $G_{\beta \gamma}$ complex. The $S T E 5^{H y p}$ alleles did not suppress ste7, ste11, ste12, or fus 3 kss1 null mutants, consistent with previous findings that the STE5 product acts before the protein kinases encoded by STE7, STE11, FUS3, and KSS1 and the transcription factor encoded by STE12. The mating defects of the ste2 deletion mutant and the temperature-sensitive ste 4-3 mutant were also suppressed by overexpression of wild-type STE5. The slow-growth phenotype manifested by cells carrying $S T E 5^{H y p}$ alleles was enhanced by the sst2-1 mutation; this effect was eliminated in ste 4 mutants. These results provide the first evidence that the $S T E 5$ gene product performs its function after the $\mathbf{G}$ protein subunits.

The pheromone response in the yeast Saccharomyces cerevisiae provides a model system for studying general features of peptide-hormone action (see references 59 and 75 for reviews). In this yeast, conjugation of haploid a and $\alpha$ cells yields $\mathbf{a} / \alpha$ diploid cells. Conjugation requires the action of peptide pheromones: a cells secrete a-factor pheromone and respond to $\alpha$-factor, whereas $\alpha$ cells secrete $\alpha$-factor pheromone and respond to a-factor. The binding of the pheromones to specific receptors on the target cell initiates the mating program. Specific cellular responses to pheromones include the arrest of cell division in $G_{1}(34)$ and the production of cellular factors required for cell aggregation, cell fusion, karyogamy, and pheromone desensitization (17, $18,54,60,72,79)$. These responses are mediated, at least in part, by changes in the transcription of cellular genes. Pheromones also provide spatial information which allows cells to locate and choose specific mating partners $(42,43$, 51).

Previous genetic analyses of the pheromone response pathway identified a number of components required for signal transduction. The STE2 and STE3 genes encode the $\alpha$-factor and a-factor receptors, respectively $(4,35,46,57$,

\footnotetext{
* Corresponding author. Mailing address: Department MGM, University of Massachusetts Medical School, 55 Lake Ave. North, Worcester, MA 01655. Phone: (508) 856-2157. Fax: (508) 856-5920.

$\dagger$ Present address: Rosenstiel Center for Biomedical Research, Brandeis University, Waltham, MA 02254.

$\ddagger$ Present address: Department of Biology, Massachusetts Institute of Technology, Cambridge, MA 02139.
}

58). The receptors are thought to span the plasma membrane seven times, thus sharing the predicted topologies of rhodopsin and the $\beta$-adrenergic receptor $(7,9,13,31,65)$. The GTP-binding regulatory protein (G protein), which has been proposed to mediate the postreceptor signal, appears to be unusual. Genetic experiments indicate that the $\mathrm{G}_{\beta \gamma}$ complex, encoded by the STE 4 and STE18 genes, activates the subsequent events in the pathway, whereas the $G_{\alpha}$ subunit, encoded by the GPAl gene (also designated $S C G 1$ ), regulates the activity of the $G_{\beta \gamma}$ complex $(2,19,35,57,61,64$, $82)$. The direct target of $G$ protein action is unknown; however, several gene products have been implicated in subsequent steps in the signal transduction pathway. Five serine/threonine protein kinases are encoded by the STE7, STE11, STE20, FUS3, and KSS1 genes $(16,25,35,53,68$, $69,78)$; the $F U S 3$ and $K S S 1$ products are redundant in function $(24,55)$. A DNA-binding protein encoded by the STE12 gene $(22,26)$ binds to a cis-acting DNA sequence (the pheromone response element) that mediates pheromoneinduced transcription $(30,50,81)$. The STE5 gene product performs a role in signal transduction which is as yet unknown $(35,37,57,63,67)$.

Mutations that cause constitutive activation of the pheromone response pathway have been invaluable for epistasis tests to determine the temporal order in which the various gene products function. Cell cycle arrest and pheromoneindependent transcription of pheromone-inducible genes have been observed for recessive alleles of the GPA1 gene $(2,19,44,61,65)$. Constitutive activation also results from special dominant alleles of the STE4 and STE11 genes $(3,8$, 
mented with $0.1 \%$ Casamino Acids (Difco). Standard genetic methods were used for all strain constructions (62).

Plasmid and strain constructions. All yeast transformations utilized the lithium acetate procedure (41). Plasmids pDJ143 and pDJ144 were constructed by ligating a 4.5-kb Bam HI$P v u I I$ fragment containing STE5 from the plasmid pHB3 (37) with the YEp352 (for pDJ143) or YIp352 (for pDJ144) vector (39) digested with BamHI and SmaI. The isolation of plasmid pDJ174 is described below; this plasmid is a mutagenized isolate of pDJ143 containing the STE5 $5^{\text {Hyp }}-1$ allele. The plasmid pDJ175 was constructed by ligating the $X b a \mathrm{I}$ fragment of pDJ174 containing STE5 ${ }^{\text {HyP }}-1$ into YIp352 digested with $\mathrm{XbaI}$. The integration of pDJ144 and pDJ175 was targeted to the chromosomal URA3 locus by digestion with ApaI, which cuts the plasmid within the URA3 gene. Recombinant plasmids of pDJ143 and pDJ174 were constructed as follows (see Fig. 1). For pDJ176, the small SacI-AflII fragment of pDJ174 was ligated to the large SacI-AflI fragment of pDJ143. For pDJ177, the large SacI-AflII fragment of pDJ174 was ligated to the small SacI-AflI fragment of pDJ143. For pDJ178, the small Asp 718 (an isoschizomer of $K p n I$ ) fragment of pDJ174 was ligated to the large Asp 718 fragment of pDJ143. The plasmid pDJ179 was constructed by ligating the small KpnI fragment of pDJ143 with the large KpnI fragment of pDJ176. Large fragments contained vector sequences, while small fragments were pieces of STE5 DNA.

The ste2-10::LEU2 allele is a nearly complete substitution of the STE2 gene with LEU2 (48). Chromosomal deletion of the STE5 gene was achieved by transforming strain DJ602136 with an $X b a I$ fragment from plasmid pSLYSEA (37), in which $L Y S 2$ replaces $98 \%$ of the coding region of $S T E 5$, to produce the strain DJ1000A. Genetic disruption of the STE4 gene (DJ656-2) was achieved by transforming the diploid strain DJ656 with a PstI-XbaI fragment from the plasmid pDJ154, containing STE4 with the LEU2 gene inserted at an internal BglII site. Deletion of the STE18 gene (DJ656-4) was achieved by transforming DJ656 with the SphI-HindIII fragment containing a $L E U 2$ substitution of the STE18 gene between the NsiI sites. The M81p12 (STE4) and M65p1 (ste18::LEU2) plasmids were kindly provided by $\mathrm{M}$. Whiteway. Deletions of the STE12 gene (DJ656-3 and DJ1014A) were constructed by transforming DJ656 and DJ211-12-1 with a SacI-SphI fragment from the plasmid pSUL16, containing STE12 sequences with $L E U 2$ replacing an internal $X b a I$ fragment (27). The STE7 gene was disrupted in DJ602136 to produce strain DJ1023A by transformation with a HindIII fragment from pDH90 (a gift from D. Higgins and K. Tatchell), containing the STE7 gene with $L E U 2$ inserted into a BglII site. Deletion of the STE11 gene was accomplished by transformation of strain DJ602-136 with a BamHI-Xhol fragment of the plasmid pSURE11, containing STE11 sequences, with the $U R A 3$ gene, flanked by Salmonella his $G$ repeats, replacing an internal HindIII fragment. An isolate in which the his $G$ repeats had recombined to remove the $U R A 3$ gene was obtained by selection on 5-fluoro-orotic acid (5) and was named DJ1003A. The plasmid pSURE11 was constructed by inserting a BamHI-BglII fragment from pNKY51 (1), containing the $U R A 3$ gene flanked by his $G$ repeats, into the HindIII-cleaved plasmid pBste11 $\Delta 1$, which was constructed by ligating into Bam HI-XhoI-cut Bluescript (Stratagene) a XhoI-BamHI fragment containing ste11 1 , the STE11 gene lacking an internal HindIII fragment (10). In the construction of pBste11 1 , the $5^{\prime}$ overhangs of both fragments were filled by using the Klenow fragment of DNA polymerase I. Genetic disruptions and deletions were confirmed by Southern blot analysis of sterile isolates (73).

Isolation of mutants. Hydroxylamine mutagenesis was performed essentially as described by Rose and Fink (71). Mutagenized plasmids were used directly for transformation of yeast cells. The level of mutagenesis was inferred by monitoring the inactivation of the URA3 gene when the plasmid was introduced into the $\mathrm{Ura}^{-}$Escherichia coli strain MH6 (pyrF). A total of $2.7 \%$ of the ampicillin-resistant transformants were $\mathrm{Ura}^{-}$. Yeast strain DJ676-2-2 (MATa leu2 ura3 sir $3^{t s}$ ) was transformed with the mutagenized pDJ143 plasmid. Transformants were selected on -Ura plates at $34^{\circ} \mathrm{C}$ and replica plated onto two - Ura plates, which were incubated at 34 and $22^{\circ} \mathrm{C}$, respectively. Plasmid DNA was extracted from colonies that exhibited coldsensitive growth (40) and were retested by transforming the parent strain, DJ676-2-2. The plasmid isolate designated pDJ174 resulted in both cold-sensitive growth and the appearance of pear-shaped cells in the culture at $22^{\circ} \mathrm{C}$. The pDJ174 and pDJ143 plasmids were used to transform strain DJ602-136 (MATa ade2 ade3) carrying the plasmid pDJ117 (MAT $\alpha A D E 3)$. This strain produces red colonies with white sectors resulting from occasional loss of the plasmid; haploid-specific growth defects block the sectoring phenotype of this strain (2). Transformants were selected on -Ura +CAA plates and scored for the ability to grow after spontaneous loss of the pDJ117 plasmid, as indicated by the appearance of sectors. Sectors were apparent in transformants containing pDJ143 but not in those containing pDJ174.

Preparation of whole-cell extracts and immunoblot analysis. Cells growing exponentially in -Ura liquid medium were collected by centrifugation, washed, and resuspended to a density of $0.5 \mathrm{~g}$ of cells (wet weight) per $\mathrm{ml}$ of lysis buffer (50 $\mathrm{mM}$ Tris [pH 6.8], 0.1 mM EDTA, $10 \%$ glycerol) containing protease inhibitors [ $1 \mathrm{mM}$ phenylmethanesulfonyl fluoride, 1 $\mathrm{mM}$ benzamidine, $0.5 \mathrm{mM}$ L-1-chloro-3-(4-tosylamido)-7amino-2-heptanone- $\mathrm{HCl}$, and $5 \mu \mathrm{M}$ pepstatin] and phosphatase inhibitors $(0.1 \mathrm{M}$ sodium pyrophosphate, $0.1 \mathrm{M}$ $\mathrm{NaN}_{3}, 0.1 \mathrm{M} \mathrm{NaF}, 4 \mathrm{mM}$ sodium EDTA, $4 \mathrm{mM}$ sodium metavanadate, and $4 \mathrm{mM}$ sodium orthovanadate). Cells were lysed by agitation with glass beads on a Vortex mixer for 10 30-s intervals separated by 30-s incubations on ice. The extract was removed, and the glass beads were rinsed twice with lysis buffer. Sodium dodecyl sulfate was added to $2 \%$ to the combined extract and rinses, and the mixture was boiled for $3 \mathrm{~min}$ and then centrifuged for $20 \mathrm{~min}$ at $12,000 \times \mathrm{g}$. The protein concentration was assayed by using the bicinchoninic acid reagent (Pierce). $\beta$-Mercaptoethanol (to 5\%) and bromphenol blue (to $0.01 \%$ ) were added to each extract. A volume containing $150 \mu \mathrm{g}$ of protein was loaded on a $6.5 \%$ polyacrylamide gel (52). Proteins were transferred electrophoretically to a nitrocellulose membrane. The STE5 gene product was detected with affinity-purified rabbit antiserum (37) and goat anti-rabbit immunoglobulin antibodies coupled to alkaline phosphatase (Bio-Rad) as recommended by the supplier.

Quantitative mating assays. The quantitative mating experiments were performed essentially as described by Hartwell (35). Cells were cultured overnight in -Ura or - Ura +CAA medium at $34^{\circ} \mathrm{C}$ to a density of between $1 \times 10^{6}$ and $2 \times 10^{7}$ cells per $\mathrm{ml}$, diluted to $1 \times 10^{6}$ cells per $\mathrm{ml}$, and shifted to $22^{\circ} \mathrm{C}$ for $3 \mathrm{~h}$ (to enhance expression of the hyperactive phenotype). To determine mating efficiency, $2 \times 10^{6} \mathrm{MATa}$ cells were mixed with $2 \times 10^{6} M A T \alpha$ tester cells (strain EMS63). The mixture was collected on a type HA nitrocellulose filter $(0.45-\mu \mathrm{m}$ pore size). The filter was rinsed and 
then transferred to a -Ura or -Ura + CAA plate at $22^{\circ} \mathrm{C}$. After $6 \mathrm{~h}$ at $22^{\circ} \mathrm{C}$, the cells were suspended in $2 \mathrm{ml}$ of minimal medium, dispersed by vortexing at high speed for $1 \mathrm{~min}$, and diluted in and plated on unsupplemented minimal medium. Diploid colonies were scored after 2 days at $30^{\circ} \mathrm{C}$. The same procedure was used to assay mating at $34^{\circ} \mathrm{C}$, except that the cultures were first grown overnight at $34^{\circ} \mathrm{C}$, and all solutions and culture media were prewarmed to $34^{\circ} \mathrm{C}$.

Plasmid loss assays. The ability of the pDJ174 plasmid to inhibit cell division was inferred from the frequency at which plasmid-deficient cells appeared under nonselective culture conditions. Diploid strains heterozygous for the allele ste2:: LEU2, ste 4::LEU2, ste12::LEU2, or ste18::LEU2 (strains DJ787, DJ656-2, DJ656-3, and DJ656-4, respectively) were transformed with either the pDJ174 $\left(S T E 5^{\text {Hyp }}-1\right)$ or the pDJ143 $\left(\right.$ STE5 $\left.^{+}\right)$plasmid, induced to sporulate, and subjected to tetrad analysis. Diploid strain DJ789 (ste4::LEU2) $+s s t 2-1 /+$ ) containing plasmid pDJ174 was processed identically. Tetrads in which the disruption segregated $2\left(\mathrm{Leu}^{+}\right)$: $2\left(\mathrm{Leu}^{-}\right)$and the plasmid segregated $4\left(\mathrm{Ura}^{+}\right): 0\left(\mathrm{Ura}^{-}\right)$were used in plasmid loss experiments. Both MATa and MAT $\alpha$ segregants were analyzed, except in the cases of the ste2-10::LEU2 deletion and sst2-1 strains, for which only $M A T$ a strains were used. All four segregants in a tetrad were tested for plasmid loss at least twice. Cells were cultured overnight in -Ura medium at $34^{\circ} \mathrm{C}$, diluted to $10^{5}$ cells per ml with YM-1, and grown to saturation (4 to 5 days) at $22^{\circ} \mathrm{C}$. Serial 10-fold dilutions were spread onto $\mathrm{C}$ and -Ura plates. The percentage of plasmid remaining was determined by the ratio of the number of $\mathrm{Ura}^{+}$colonies to the total number of colonies on the $\mathrm{C}$ plates. If more than $15 \%$ of the cells retained the plasmid, the plasmid was considered stable. If fewer than $3 \%$ of the cells retained the plasmid, it was considered unstable.

Assays of $\beta$-galactosidase activity. Assays of $\beta$-galactosidase in cell extracts were performed as described by Hagen and Sprague (32). Cultures were grown to exponential phase in -Ura-Trp+CAA at $34^{\circ} \mathrm{C}$, diluted to about $5 \times 10^{\circ}$ cells per $\mathrm{ml}$, and shifted to $22^{\circ} \mathrm{C} 3 \mathrm{~h}$ prior to assay. Cells were collected by centrifugation and resuspended in 0.1 volume of $\mathrm{Z}$ buffer $\left(10 \mathrm{mM} \mathrm{KCl}, 1 \mathrm{mM} \mathrm{MgSO}_{4}, 50 \mathrm{mM} \beta\right.$-mercaptoethanol, $0.1 \mathrm{M}$ sodium phosphate, $\mathrm{pH} 7$ ). To make the cells permeable, toluene (to $1 \%$ ) and sodium sarcosyl (to $5 \%$ ) were added, and the mixture was vortexed and incubated at $37^{\circ} \mathrm{C}$ for $30 \mathrm{~min}$. Enzyme activity was measured at $28^{\circ} \mathrm{C}$ in 22 $\mathrm{mM} O$-nitrophenyl- $\beta$-D-galactoside- $0.1 \mathrm{M}$ sodium phosphate, $\mathrm{pH}$ 7. A one-third volume of $\mathrm{Na}_{2} \mathrm{CO}_{3}$ was added to terminate the reaction, and the $A_{420}$ was measured after clarification by centrifugation. Units of activity were calculated by using the formula $\left(1,000 \times A_{420}\right.$ of reaction $) \div\left(A_{600}\right.$ of culture $x$ volume [in milliliters] of culture used $\times$ time of reaction [in minutes]).

\section{RESULTS}

Isolation of the $S T E 5^{\text {Hyp }}$-1 allele. We sought a mutant allele of the STE5 gene that would cause constitutive activation of the pheromone response pathway. The STE5 gene product is thought to be a positive regulatory element in the pathway, since null alleles result in loss of pheromone responsiveness $(35,37,57)$. Hence, it was anticipated that constitutive STE5 alleles would be associated with a gain of function and would therefore be dominant. Furthermore, since expression of the STE5 gene is regulated by the mating-type locus $(28,63,67)$, the mutant alleles were expected to cause arrest of cell division in haploid cells, which contain either the MATa locus or the MAT $\alpha$ locus, but to have no effect on the growth of diploid cells, which contain both loci. Similarly, haploid cells bearing the $s i r 3^{2 s}$ mutation $(35,70)$ as well as the constitutive STE5 allele should grow at 34 but not at $22^{\circ} \mathrm{C}$, because at the higher temperature sir $3^{t s}$ cells express the normally silent mating-type information, $\alpha$ and a, located at the $H M L$ and $H M R$ loci, respectively.

A high-copy-number episomal plasmid carrying the STE5 gene, pDJ143, was mutagenized with hydroxylamine and used to transform a sir $3^{t s}$ strain (DJ676-2-2). Transformants were selected at $34^{\circ} \mathrm{C}$ and then transferred to duplicate plates that were incubated at 22 and $34^{\circ} \mathrm{C}$, respectively. Further analysis was performed for isolates that grew normally at $34^{\circ} \mathrm{C}$ but divided more slowly at $22^{\circ} \mathrm{C}$ and accumulated the pear-shaped cells (shmoos) associated with pheromonetreated cells. From a total of 231 transformants, 12 coldsensitive colonies were isolated, and their plasmid DNA was used to retransform the parent sir $3^{t s}$ strain. Four candidate plasmids conferred a growth defect at $22^{\circ} \mathrm{C}$, but only one also resulted in a significant number of pear-shaped cells. This mutant plasmid was designated pDJ174, and the "hyperactive" allele was designated STE $5^{\text {Hyp }}$-1.

Haploid-specific inhibition of growth. Additional lines of evidence supported the conclusion that plasmid pDJ174 causes an inhibition of growth that is specific to haploid cells. A colony-sectoring assay was previously used to identify haploid-specific mutants (2). In that method, a $M A T$ a ade 2 ade 3 parent strain carrying an $A D E 3 M A T \alpha$ plasmid (pDJ117) was used; such a strain produces red colonies with white sectors that arise as a result of plasmid instability (49). Mutations that cause a haploid-specific growth defect, such as gpal and STE4 ${ }^{H p l}$, prevent the division of cells lacking the plasmid and thereby block the formation of white sectors (2). For the present study, strain DJ602-136 containing plasmid pDJ117 was transformed with the mutant plasmid pDJ174 and with the control plasmid pDJ143. Isolates carrying the pDJ143 plasmid produced white sectors, but the pDJ174 transformants did not, indicating that the plasmid pDJ174 conveys a haploid-specific growth defect.

Growth inhibition was also evident among the haploid segregants of the diploid strain DJ656 containing plasmid pDJ174. Tetrad analysis of the diploid cells containing the control plasmid pDJ143 gave rise to segregants that showed normal colony size. In contrast, the strain containing pDJ174 yielded spores that exhibited a variety of phenotypes upon germination: single cells with a pear shape, small Ura ${ }^{+}$ colonies that contained the plasmid, and larger Ura ${ }^{-}$colonies that did not contain the plasmid. Presumably, the copy number of the pDJ174 plasmid at the time of germination determined whether the spore exhibited arrest of cell division in the first cycle or produced a small colony. Consistent with this view, diploid cells containing one integrated copy of the STE5 $5^{\text {Hyp }}-1$ gene on plasmid pDJ175 never yielded spores which arrested division in the first cycle, and the resulting colonies showed no obvious growth defect. The phenotype of the pDJ174 plasmid appeared to be more extreme at 22 than at $34^{\circ} \mathrm{C}$, since a larger fraction of the spores that germinated at the lower temperature arrested in the first cycle. Consequently, in most of our subsequent studies haploid cells that carried a $S T E 5^{H y p}$ allele were propagated at $34^{\circ} \mathrm{C}$ and then shifted to $22^{\circ} \mathrm{C}$ for stronger expression of the hyperactive phenotype.

Sequence analysis of STE5 ${ }^{H y p}$-1. As discussed below, the mutant plasmid pDJ174 suppresses the sterility phenotype of ste 4 mutants; this phenotype was used to map the nucleotide 


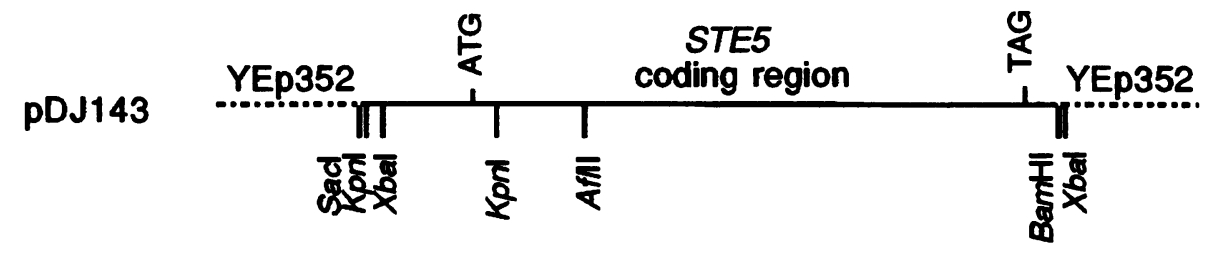

Plasmid

Mating efficiency

in ste $4^{-}$cells

(\% of STE ${ }^{+}$mating)

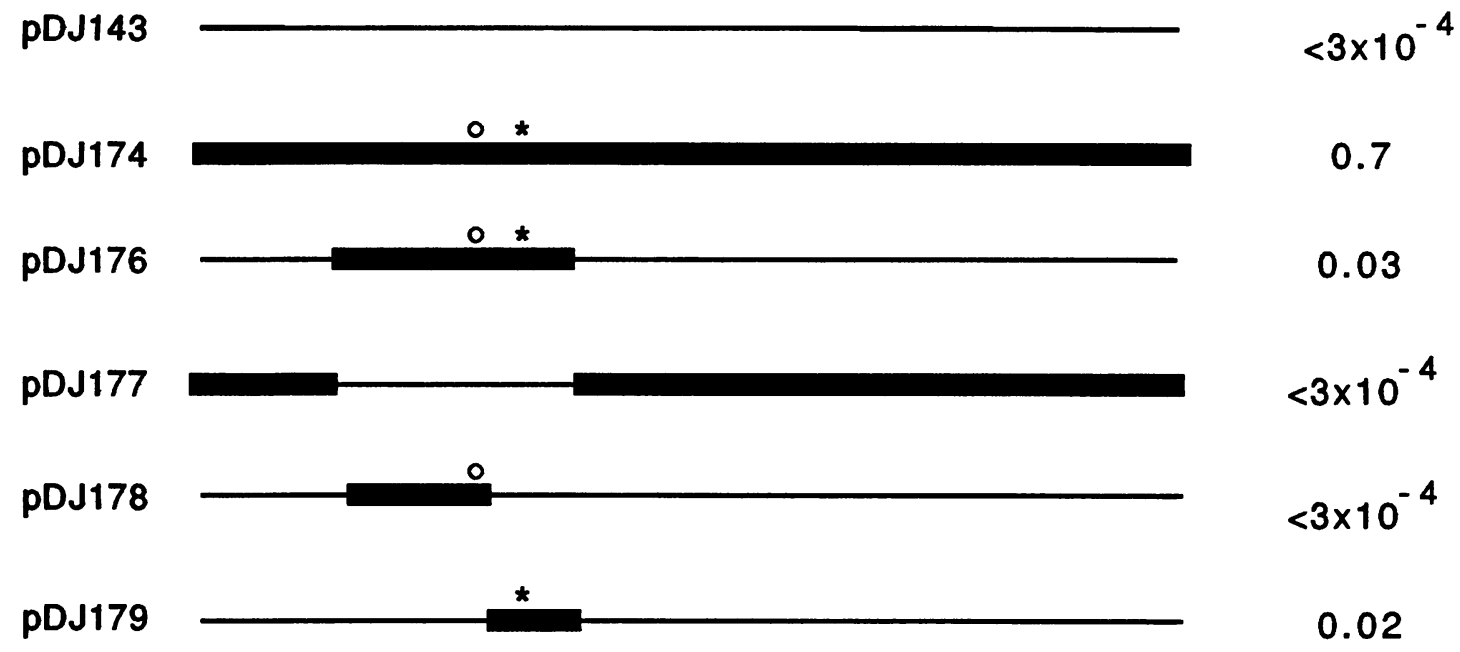

$1 \mathrm{~kb}$

FIG. 1. A single base pair change in the STE5 coding sequence confers a hyperactive phenotype. A schematic diagram of the restriction map of the $S T E 5^{+}$plasmid pDJ143 is shown at the top. The diagram below shows the locations, relative to this map, of wild-type (thin lines) or mutant (thick lines) sequences in the recombinant plasmids. Mutational differences indicated by $\bigcirc$ and * were identified by DNA sequence analysis. The mutation responsible for the hyperactive phenotype (*) is a C-to-T transition in the coding sequence of STE5 which is predicted to cause a Thr-to-Met change at position 52 of the protein $(37,63,67)$. The silent mutation $(O)$ causes a Ser-to-Arg substitution at position 18. The mating efficiency of the strain 381 GUL $\triangle$ STE4 containing each plasmid is indicated, relative to that of a STE $4^{+}$strain, which produced $3 \times 10^{6}$ diploids in the quantitative mating assay. The assay methods were the same as used for Table 2 , except that filters were incubated on -Ura+CAA plates.

change responsible for the phenotype of $\mathrm{pDJ} 174$. The presence of pDJ174 improved the mating ability of ste 4 mutants more than 1,000-fold compared with that of cells carrying the control plasmid pDJ143 (Fig. 1). In the recombinant plasmid pDJ176, mutant sequences replaced wild-type sequences in the promoter and approximately the first quarter of the STE5 coding sequence. This plasmid possessed most of the ability of the original isolate to suppress the sterility of ste 4 strains, while the plasmid containing the opposite combination of mutant and wild-type sequences, pDJ177, had no such ability. When the protein-coding region of the mutant gene contained in plasmid pDJ176 was sequenced, two nucleotide changes were found. These two changes were separated, in plasmids pDJ178 and pDJ179. Only pDJ179 was found to confer suppression (Fig. 1, last two lines); thus, a single mutation in the coding region of the wild-type STE5 sequence was sufficient to cause a constitutive phenotype. The mutation in plasmid pDJ179, a C-to-T transition, is predicted to cause a change of a threonyl to a methionyl residue at position 52 in the $S T E 5$ gene product $(37,63,67)$; this mutant allele was designated $S T E 5^{\text {Hyp }}$-2. The stronger phenotype associated with pDJ174 is apparently due to an unidentified mutation(s) elsewhere in the plasmid that enhances the phenotype of $S T E 5^{H y P}$-2; these mutations must be either in the C-terminal portion of the STE5 coding region or in vector sequences. Since these mutations in plasmid pDJ177 had no detectable phenotype, they were not analyzed further.

To test whether pDJ179 confers a growth defect, we measured the growth rates of a wild-type haploid strain, YPH499, when it was carrying either the parent vector YEp352, the $S T E 5^{+}$plasmid pDJ143, or the $S T E 5^{H y p_{-} 2}$ plasmid pDJ179. For two independent transformants of each plasmid, the culture doubling times at $34^{\circ} \mathrm{C}$ were determined and averaged. The strain carrying the vector alone grew with a generation time of $1.8 \pm 0.2 \mathrm{~h}$. The wild-type STE5 gene in multiple copies did not affect the growth rate perceptibly (1.9 $\pm 0.2 \mathrm{~h}$ ). However, the presence of the single base change in $S T E 5^{H y p_{-} 2}$ lengthened the generation time to $2.8 \pm 0.6 \mathrm{~h}$. 


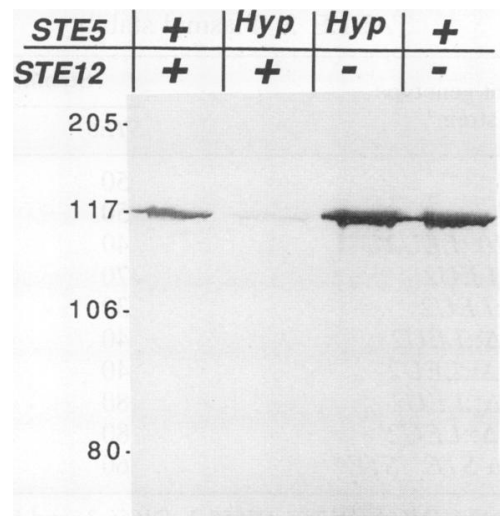

FIG. 2. Levels of STE5 protein in mutant and wild-type strains. Cell extracts $(150 \mu \mathrm{g}$ of total protein) were resolved by sodium dodecyl sulfate-polyacrylamide gel electrophoresis, and the proteins were transferred electrophoretically to nitrocellulose and probed with an affinity-purified antiserum that recognizes the STE5 gene product. Strains used were DJ211-12-1 $\left(S T E 12^{+}\right)$and DJ1014A (ste12). Cells carry the STE5 plasmid pDJ143 (+) or pDJ179 (Hyp) as indicated; the latter contains the STE $5^{\text {Hyp }}$-2 allele. The positions of the protein molecular weight markers (kilodaltons) are indicated.

The lower growth rate of the strain containing pDJ179 was apparently due to a longer period in the $G_{1}$ phase of the division cycle. As judged from flow cytometry of propidium iodide-stained cells, the proportion of cells in the $\mathrm{G}_{1}$ phase was $45 \%$ for the culture containing pDJ179, while it was 32 and $26 \%$ for the cultures containing pDJ143 and YEp352, respectively.

Levels of STE5 gene product. We considered the possibility that phenotypes associated with the STE $5^{H y P}$ mutants were a consequence of an increased accumulation of the gene product. Immunoblot analysis was performed on extracts of cells carrying either the $S T E 5^{+}$plasmid pDJ143 or the STE5 $5^{\text {Hy }}$-2 plasmid pDJ179 (Fig. 2). The antiserum (37) was raised against a $\mathrm{C}$-terminal fragment of the STE5 product that does not include the residue altered in the mutant protein. We found that the amount of STE5 gene product recovered from cells carrying pDJ179 was in fact less than the amount recovered from the control cells carrying pDJ143. The lower level of mutant protein may be due to a growth advantage for the cells that carry fewer copies of the plasmid. Consistent with this view, plasmids pDJ143 and pDJ179 led to equal amounts of STE5 protein in a ste12 strain, in which STE5 ${ }^{\text {Hyp }}$ does not cause a growth disadvantage (see below). Hence, the phenotype of the STE5 $5^{H y p}-2$ mutant is not due simply to a higher level of the gene product; rather, the phenotype persists despite a relatively low level of the mutant protein.

Suppression of sterility. The combined phenotype caused by mutations affecting two different steps in a cellular process can provide information about the order in which the two gene products function $(38,45)$. Constitutive activation of the pheromone response pathway caused by a $S T E 5^{\text {Hyp }}$ mutation should bypass the mating defect imposed by a block of an earlier step of the pathway. This approach was used by other investigators $(14,44,77)$ to show that the constitutive gpa 1, srm1, and cdc72 mutants could bypass the block caused by a deletion of the receptor structural gene, STE2. Similarly, cells containing both the constitutive $S T E 4^{H p l}$ mutation and the conditionally unresponsive ste5-3 mutation do not respond to pheromone and fail to exhibit the
TABLE 2. Mating efficiency

\begin{tabular}{|c|c|c|c|c|c|}
\hline \multirow{3}{*}{$\begin{array}{l}\text { Relevant genotype } \\
\text { of strain }{ }^{a}\end{array}$} & \multicolumn{4}{|c|}{ Diploids produced ${ }^{b}$} & \multirow{3}{*}{$\begin{array}{c}\text { Temp } \\
\left({ }^{\circ} \mathrm{C}\right)\end{array}$} \\
\hline & \multicolumn{2}{|c|}{ YEp plasmid } & \multicolumn{2}{|c|}{ YIp plasmid } & \\
\hline & STES & $S T E 5^{H y p}$ & STES & $S T E 5^{\text {HP }}$ & \\
\hline$S T E^{+}$ & $3 \times 10^{6}$ & $1 \times 10^{6}$ & $2 \times 10^{6}$ & $2 \times 10^{6}$ & 22 \\
\hline ste2-10::LEU2 & $4 \times 10^{2}$ & $1 \times 10^{3}$ & $<10$ & $<10$ & 22 \\
\hline ste4::LEU2 & $<10$ & $1 \times 10^{3}$ & $<10$ & $<10$ & 22 \\
\hline ste $4 \Delta:: L E U 2$ & $<10$ & $2 \times 10^{3}$ & $\mathrm{ND}^{c}$ & ND & 22 \\
\hline ste7::LEU2 & $<10$ & $<10$ & ND & ND & 22 \\
\hline ste11 & $<10$ & $<10$ & ND & ND & 22 \\
\hline ste12 $\Delta:: L E U 2$ & $<10$ & $<10$ & ND & ND & 22 \\
\hline ste18 $\Delta:: L E U 2$ & $<10$ & $2 \times 10^{4}$ & ND & ND & 22 \\
\hline ste4-3 & $2 \times 10^{3}$ & $3 \times 10^{5}$ & 30 & $4 \times 10^{4}$ & 34 \\
\hline$S T E^{+}$(YPH499) & $4 \times 10^{6}$ & ND & ND & ND & 22 \\
\hline $\begin{array}{l}f u s 3-6:: L E U 2 \\
\quad k s s 1 \Delta:: H I S 3\end{array}$ & $<10$ & $<10$ & ND & ND & \\
\hline
\end{tabular}

a Strains used in these experiments were derived as haploid MAT segregants of the diploid strain DJ656, DJ787, DJ656-2, DJ656-3, DJ656-4, or DJ783. Other strains were transformants of the haploid strain 381GULASTE4, DJ1023A, DJ1003A, YPH499, or YPH499fus3kss1. For wild-type strains, the strain name is in parentheses. All other strains except YPH499fus3kss1 and YPH499 are congenic to 381G. Strain YPH499fus3kss1 is derived from YPH499.

${ }^{b}$ Data are the number of colonies growing on the unsupplemented minimal plates multiplied by the dilution factor. Strains carried one of the following plasmids, as indicated: pDJ143 (YEp STE5); pDJ174 (YEp STE5 ${ }^{\text {Hyp }}$ ), containing $S T E 5^{H y p}$. 1 for all strains except the fus 3 kss 1 strain, which carried pDJ179, containing STE5 $5^{H y p}$-2; pDJ144 (YIp STE5); or pDJ175 (YIp STE5 ${ }^{H y p}$ ), containing STE5 $5^{\text {Hyp }}$-1.

$c \mathrm{ND}$, not determined.

constitutive-arrest phenotype of $S T E 4^{H p l}$ at the restrictive temperature for ste5-3 (2). This result suggests either that the STE5 gene product functions after the STE4 product or that the two proteins affect the same event in the signal transduction pathway. The $S T E 5^{\text {Hyp }}$ mutant permitted a resolution of this ambiguity. Analysis of double mutants was also used to examine the relationships of the STE5 product to the $\alpha$-factor receptor, encoded by STE2; the $\mathrm{G}_{\gamma}$ subunit, encoded by STE18; a DNA-binding protein, encoded by STE12; and protein kinases involved in pheromone signal transduction, encoded by STE7, STE11, FUS3, and KSS1.

Double mutants were generated in two ways: (i) ste mutants were transformed directly with pDJ174, pDJ179, or pDJ143, and two independent transformants of each plasmid were tested for mating ability; or (ii) diploid strains heterozygous at a STE locus were transformed with the STE5 plasmids and induced to sporulate, the resulting asci were dissected, and ste segregants that carried a plasmid were tested for mating ability. The results are presented in Table 2. The mating defect of the ste2 strain was partially suppressed by either the plasmid pDJ174, containing $S T E 5^{H y P}-1$, or the plasmid pDJ143, containing STE5 ${ }^{+}$. The ste 4 and ste 18 null mutants were partially suppressed by pDJ174, while pDJ143 did not increase mating to a detectable level. STE5 $5^{\text {HyP }}-1$ could not suppress the mating defect caused by a disruption of the STE7 gene or by deletion of the STE11 or STE12 gene, nor could $S T E 5^{H y P}-2$ suppress a combined deletion of the FUS3 and KSS1 genes. These results suggest that the STE5 gene product acts after the G protein on the signal transduction pathway and that it acts either before or at the same step as the protein kinases and the transcription factor. These results are in agreement with recent reports that ste 5 mutants are unable to block the phenotype of a constitutive $S T E 11$ allele $(8,29,76)$. 
When the integrating plasmid pDJ175 or pDJ144 was introduced into the chromosome at the URA3 locus, we found no suppression of the ste2-10::LEU2 or the ste4:: $L E U 2$ null allele (Table 2). Apparently, a high dosage of the $S T E 5^{H y p_{-}} 1$ gene is required in order to provide a signal sufficient for mating in the absence of those gene products. In contrast, the mating defect of the temperature-sensitive

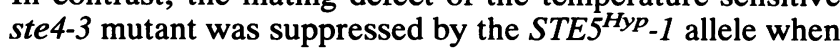
it was integrated at the chromosomal URA3 locus in a single copy (Table 2). We also found that multiple copies of $S T E 5^{+}$ could suppress the temperature-sensitive allele of STE4, in agreement with the previous observation of MacKay (56). Thus, less $S T E 5^{\text {Hyp }}$-1 product is needed for suppression of ste4-3 than for suppression of a disruption of the gene; even the wild-type STE5 gene product, at high enough levels, suffices. The allele-specific suppression of the ste 4 mutants is consistent either with a direct interaction between the STE4 and STE5 products or with a weak signal generated by the ste 4-3 product at the restrictive temperature which can be amplified in a separate step either by the STE $5^{\text {Hyp }}$ product or by overproduction of the $S T E 5^{+}$product. If direct interactions do occur, they are unnecessary for the constitutive signal generated by the $S T E 5^{H y p_{-}}-1$ and $S T E 5^{H y p_{-}}-2$ products when they are expressed from high-copy-number plasmids, since these plasmids suppressed a ste 4 deletion mutant (Table 2 and Fig. 1).

Suppression of the slow growth phenotype by ste mutations. Because cells containing mutant plasmid pDJ174

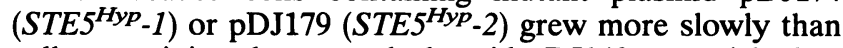
cells containing the control plasmid pDJ143, we wished to determine whether normal growth rates could be restored by blocking specific steps in the pheromone response pathway. The ability of the mutant pDJ174 to inhibit cell division was inferred from the frequency at which cells lacking the plasmid appeared under nonselective culture conditions. The percentage of cells containing the plasmid should be a sensitive measure of the relative growth rate of cells with and without the plasmid, because cells that have lost the plasmid will grow faster and take over the population. The relative abilities of the ste mutant and $S T E^{+}$cells to retain plasmids are summarized in Table 3. Plasmid pDJ174 $\left(S T E 5^{H y p}-1\right)$ was maintained poorly in $S T E^{+}$and $M A T$ a ste 2 cells ( $\leq 3 \%$ retention), whereas it was relatively stable ( $\geq 20 \%$ retention) in cells containing ste $4,-5,-7,-11$, or -12 or in $a / \alpha$ diploid cells. In contrast, the stability of control plasmid pDJ143 $\left(\right.$ STE5 $\left.5^{+}\right)$was unaffected by ste mutations or the $M A T$ locus. Plasmid pDJ179 (STE5 ${ }^{\text {HyP }}$-2) was also unstable in a wild-type host (data not shown). Hence, mutations in the STE4, STE12, and STE18 genes block the ability of pDJ174 to inhibit cell division. The effects of the ste 4 and ste18 mutations were unexpected, since pDJ174 permits mating in the complete absence of STE4 and STE18 gene function (Table 2). Together, the data indicate that the product of the $S T E 5^{\text {Hyp }}-1$ gene can activate the pheromone pathway in the absence of the pheromone receptor and the $G$ protein but that for full activity it requires $G_{\beta \gamma}$.

Increase in transcription from a pheromone-inducible promoter. A pheromone-inducible reporter gene was used to examine the activation of the pheromone response pathway in the various ste mutants. The reporter plasmid pDJ10 (80) carries an $\alpha$-factor-inducible promoter (containing eight copies of the pheromone response element) fused to the coding sequence of the lac $Z$ gene. When this construct is expressed in wild-type $M A T$ a cells, $\alpha$-factor pheromone stimulates the production of $\beta$-galactosidase by more than 10 -fold (80). Both plasmids pDJ143 $\left(\right.$ STE5 $\left.^{+}\right)$and pDJ179 $\left(\right.$STE5 $\left.{ }^{\text {Hyp }}-2\right)$ led
TABLE 3. Plasmid stability

\begin{tabular}{|c|c|c|}
\hline \multirow{2}{*}{$\begin{array}{l}\text { Relevant genotype } \\
\text { of strain }\end{array}$} & \multicolumn{2}{|c|}{ Stability of plasmid $b$} \\
\hline & STE5 & $S T E 5^{H y p}$ \\
\hline$M A T$ a $S T E^{+}$ & 50 & 2 \\
\hline$M A T \alpha S T E^{+}$ & 50 & 2 \\
\hline$M A T$ a ste2-10::LEU2 & 40 & 3 \\
\hline$M A T$ a ste $4:: L E U 2$ & 70 & 20 \\
\hline$M A T \alpha$ ste $4:: L E U 2$ & 30 & 20 \\
\hline$M A T$ a ste $12 \Delta:: L E U 2$ & 40 & 20 \\
\hline$M A T \alpha$ ste $12 \Delta:: L E U 2$ & 40 & 20 \\
\hline$M A T$ a ste $18 \Delta:: L E U 2$ & 80 & 40 \\
\hline$M A T \alpha$ ste $18 \Delta:: L E U 2$ & 80 & 20 \\
\hline$M A T \mathrm{a} / M A T \alpha S T E^{+} / S T E^{+}$ & 60 & 50 \\
\hline
\end{tabular}

${ }^{a}$ Diploid strains DJ656, DJ787, DJ656-2, DJ656-3, and DJ656-4, heterozygous for the ste allele indicated, were transformed with plasmid pDJ143 or pDJ174. Tetrads from these strains in which the disruption segregated 2 $\left(\mathrm{Leu}^{+}\right): 2\left(\mathrm{Leu}^{-}\right)$and the plasmid segregated $4\left(\mathrm{Ura}^{+}\right): 0\left(\mathrm{Ura}^{-}\right)$were used in plasmid loss experiments. In the case of the ste2-10::LEU2 deletion, only MATa strains were used. All four segregants in a tetrad (two ste mutant and two $S T E^{+}$) were tested in parallel for plasmid loss at least twice, and results of the independent determinations were averaged.

${ }_{b}$ Data are the percentage of cells retaining plasmid pDJ143 (STE5) or pDJ174 (STE5 Hyp. 1), as determined after the cells had been cultured for a defined period in the absence of selection for the plasmid. Strains retaining less than $10 \%$ of the plasmid were considered unstable.

to constitutive transcription of the reporter gene in the $S T E^{+}$ strain as judged by the increased level of $\beta$-galactosidase activity in the absence of pheromone (Table 4). Furthermore, the effect of the $S T E 5^{H y p}-2$ mutation on constitutive expression is independent of the presence or absence of normal STE5 at the chromosomal location (compare STE ${ }^{+}$ with ste $5 \Delta 1: L Y S 2$ ). In other experiments (data not shown), either a single copy (pDJ175) or multiple copies (pDJ174) of the $S T E 5^{H y p}$ - 1 allele also caused an approximately 10 -fold increase in transcription. When the pheromone response pathway was blocked in ste2, ste 4 , and ste 18 mutants, the presence of the pDJ179 plasmid still resulted in an increased accumulation of $\beta$-galactosidase activity, whereas it was unable to effect an increase in this activity in the ste7, ste11,

TABLE 4. Effect of STE5 activity on transcription from a pheromone-inducible promoter

\begin{tabular}{|c|c|c|c|}
\hline \multirow{2}{*}{$\begin{array}{l}\text { Relevant genotype } \\
\text { of strain }{ }^{a}\end{array}$} & \multicolumn{3}{|c|}{$\beta$-Galactosidase activity ${ }^{b}(\mathrm{U})$} \\
\hline & Vector & STE5 & $S T E 5^{\text {Hyp }-2}$ \\
\hline$S_{T E}^{+}(\mathrm{DJ} 602-136)$ & 3 & 20 & 50 \\
\hline ste2-10::LEU2 & 10 & 60 & 90 \\
\hline ste4::LEU2 & 0.2 & 0.2 & 20 \\
\hline ste $18 \Delta:: L E U 2$ & 0.3 & 0.3 & 20 \\
\hline ste $5 \Delta 1:: L Y S 2$ & 0.3 & 30 & 60 \\
\hline ste7::LEU2 & 0.04 & 0.04 & 0.04 \\
\hline ste11 $1:$ hisG & 0.04 & 0.05 & 0.05 \\
\hline ste12A::LEU2 & 0.02 & 0.02 & 0.02 \\
\hline $\mathrm{STE}^{+}$(YPH499) & 2 & 20 & 30 \\
\hline fus3-6::LEU2 kss1D::HIS3 & 0.05 & 0.05 & 0.04 \\
\hline
\end{tabular}

a The MATa strains DJ602-136, DJ213-6-3, DJ1004-11-1, DJ1000A, DJ1023A, DJ1003A, DJ1005-9-1, DJ1006-17-2, YPH499, and YPH499fus3kss1 were used. For wild-type strains, the strain name is in parentheses. All strains except YPH499 and YPH499fus3kss1 were congenic to strain 381G.

$b$ Results are the averages of those from at least two independent transformants containing both the reporter plasmid JD10 (80) and the plasmid indicated. When treated with $2.3 \times 10^{-6} \mathrm{M}$ synthetic $\alpha$-factor for $45 \mathrm{~min}$, the wild-type strain DJ602-136 carrying YEp352 gave $30 \mathrm{U}$ of $\beta$-galactosidase activity. Strains contained the YEp-based plasmid YEp352 (vector), pDJ143 (STE5), or pDJ179 (STE5 ${ }^{\text {Hyp }}$-2). 


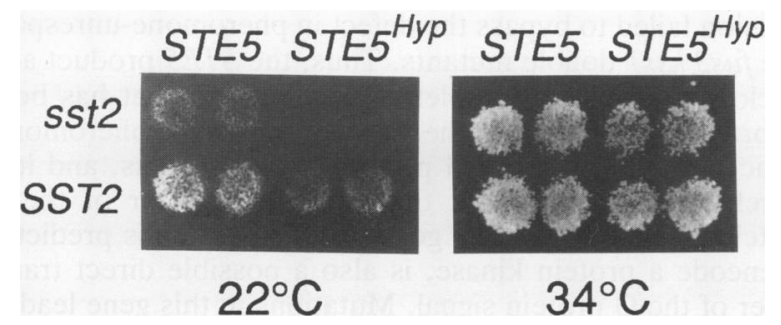

FIG. 3. The sst2-1 mutation enhances the growth defect of the STE5 ${ }^{\text {Hyp }}$-1 mutant. Strains DJ676-2-2 (sir $\left.{ }^{t s}\right)$ and DJ788-7-1 (sir $3^{t s}$ sst2) were transformed with plasmid pDJ174, which contains $S T E 5^{H y P}-1$, or pDJ143, which contains $S T E 5^{+}$. Two independent transformants $\left(10 \mu \mathrm{l}\right.$ of a stock grown to saturation at $\left.34^{\circ} \mathrm{C}\right)$ were spotted on a plate, incubated overnight at $22^{\circ} \mathrm{C}$, and replica plated twice at 22 or $34^{\circ} \mathrm{C}$.

ste12, or fus3 kss1 strain. These results are consistent with the results of the assays for suppression of sterility and for plasmid loss, namely, that the $S T E 5^{H y p}$ mutants can partially bypass the absence of the $\mathrm{G}_{\beta \gamma}$ subunit (ste4 and ste18) but not the absence of the kinases (ste7, ste11, and fus $3 \mathrm{kss} 1$ ) or of the transcription factor (ste12). The mutant STE5 Hyp product appears to be qualitatively different from the wildtype product, since pDJ143 $\left(S T E 5^{+}\right)$has no detectable effect in cells containing null alleles of STE4 or STE18, whereas pDJ179 (STE5 HyP $_{-2}$ ) increases transcription 100 -fold. Thus, the single amino acid change encoded by pDJ179 seems to make the protein at least partially independent of upstream events in the signal transduction pathway.

The basal level of transcription, observed in the strains carrying the vector plasmid, was influenced by the mutations listed in Table 4. The level of $\beta$-galactosidase activity was reduced in the ste4, ste5, and ste18 mutants, and the level was reduced still further in the ste11, ste 12, and fus $3 \mathrm{kss} 1$ mutants. The basal level of transcription in the ste 2 mutant was consistently higher than that in the $S T E^{+}$control. Similar results were obtained for basal levels of agglutinin production in ste 2 mutants (44); thus, the receptor appears to have a weak negative influence on the response pathway in the absence of pheromone.

Effects of the sst2 mutation. The fact that cells containing $S T E 5^{\text {Hyp }}$ are able to divide (albeit slowly) may be in part a consequence of the adaptation mechanisms that permit cells to recover from the pheromone-induced arrest of cell division. The wild-type SST2 gene product is required for cells to recover from pheromones $(11,12)$; it is also necessary for recovery from the signal generated in the $S T E 4^{H p l}$ mutant (3). We therefore examined the effect of an sst 2 mutation on the growth of the cells carrying the STE $5^{H y p}$ alleles. An sst2 sir $3^{\text {ts }}$ strain was constructed and transformed with plasmids pDJ174 (STE5 ${ }^{\text {Hyp }}$-1), pDJ179 (STE5 Hyp $\left._{-2}\right)$, and pDJ143 $\left(S T E 5^{+}\right)$. Growth of the transformants was examined at temperatures that were permissive $\left(22^{\circ} \mathrm{C}\right)$ and nonpermissive $\left(34^{\circ} \mathrm{C}\right)$ for the sir $3^{t s}$ mutant (Fig. 3). At $22^{\circ} \mathrm{C}$ the $S S T 2^{+} \operatorname{sir} 3^{t s}$ strain containing the $S T E 5^{H y p_{-}} 1$ plasmid $\mathrm{pDJ} 174$ grew more slowly than the same strain containing the $S T E 5^{+}$plasmid pDJ143. The sst 2 sir $3^{t s}$ strain carrying pDJ174 showed the most severe growth defect, an observation that is consistent with the idea that the SST2 gene product is involved in attenuation of the signal caused by the STE $5^{\text {Hyp }}-1$ mutation; such attenuation might affect the pathway either upstream or downstream of the STE5-controlled step. Moderate slowing of growth by the pDJ143 plasmid in an sst 2 sir $3^{t s}$ strain probably reflects the partial activation of the signalling pathway caused by increased expression of STE5 (Table 4). Plasmid pDJ179, containing the STE5 $5^{\text {Hyp }}-2$ allele, had generally the same effect as pDJ174, but its effect was slightly less pronounced (36), and the weak effect of sst 2 in the strain containing plasmid pDJ143 (YEp STE5 ${ }^{+}$) was not observed with the vector control plasmid YEp352 (36). At $34^{\circ} \mathrm{C}$, the restrictive temperature for sir $3^{t s}$, all strains exhibited normal growth.

We attempted to test the effect of the $s s t 2$ mutation in a SIR3 $^{+}$strain carrying pDJ174, but we were unable to construct such a strain, presumably because of an extreme growth defect. In subsequent crosses it became apparent that this extreme growth defect was suppressible by the ste 4 mutation. When the ste 4 strain DJ656-2-8-3 carrying pDJ174 was crossed with the sst2 strain DJ786-11-1, we found that the sst 2 mutation was absent in the 12 STE4 $4^{+}$segregants carrying pDJ174, whereas it was present in the ste 4 segregants and in $S T E 4^{+}$segregants lacking the pDJ174 plasmid (data not shown). In an additional experiment, we tested whether the ste 4 mutation was required for the sst 2 mutation to influence the growth defect caused by plasmid pDJ174. When we constructed congenic sst 2 ste 4 and $S S T 2^{+}$ste 4 strains (DJ656-2-6-2, DJ656-2-10-1, DJ789-2-2, DJ789-3-1, DJ789-5-2, and DJ789-5-3) containing plasmid pDJ174, we found that the plasmid stabilities in these strains were indistinguishable. Together these results indicate that the effect of the sst 2 mutation on the STE5 $5^{\text {Hyp }}$ phenotype requires the activity of the $S T E 4$ product, raising the possibility that the action of the $S S T 2$ gene product on the pheromone response pathway is mediated at the level of the $\mathrm{G}$ protein.

\section{DISCUSSION}

In this report, we describe an alteration of the $S$. cerevisiae STE5 gene which results in partial constitutive activation of the pheromone response pathway. We exploited this phenotype for the purpose of determining the relative order of events in the pathway. The $S T E 5^{H y p}-1$ allele was identified by mutagenizing a plasmid containing the STE5 gene and screening yeast transformants for a haploid-specific growth defect. The $S T E 5^{H y P}-2$ allele, containing a single mutation present in $S T E 5^{H y P}-1$, differs from the wild-type gene at a single base pair yet confers all of the phenotypes of the original $S T E 5^{H y p}$-1 allele. In addition to the haploid-specific growth phenotype, both $S T E 5^{H y p}$ alleles led to increased transcriptional activity of a pheromone-inducible gene in the absence of pheromone. Although the phenotype caused by $S T E 5^{H y p}$-2 is slightly weaker than that of the original isolate, no other mutation in the plasmid containing $S T E 5^{H y p_{-}} 1$ had an independent effect that was detectable in our assays. The phenotypes of both alleles are highly dependent on plasmid copy number, since single integrated copies of STE5 $5^{\text {Hyp }}$ caused no growth defect and were unable to suppress the sterility of ste 4 and ste18 deletion strains. Furthermore, the majority of the segregants which inherited YEp STE5 $5^{\text {Hyp }}$ in tetrad analysis arrested growth as single pear-shaped cells, whereas other segregants were able to divide at a rate that was slower than that of the wild type. These slowly growing segregants as well as simple transformants were used to analyze the effects of the plasmid on mating and growth.

The single base change in $S T E 5^{\text {Hyp }_{-}-2}$ is predicted to cause the substitution of a methionyl for a threonyl residue at position 52 in the coding sequence of the wild-type STE5 gene product $(37,63,67)$. In the wild-type $S T E 5$ product, Thr-52 is found in the sequence Lys-Lys-Trp-Thr-Glu-Lys, 
which is a consensus site for phosphorylation by both cyclic AMP-dependent protein kinase and protein kinase C. However, when cells containing plasmid pDJ143 $\left(\right.$ STE5 $\left.{ }^{+}\right)$or pDJ179 (STE5 $\left.5^{\text {Hyp }}-2\right)$ were labelled in vivo with ${ }^{32} \mathrm{P}_{\mathrm{i}}$ and the STE5 products were purified, we detected no difference between the two-dimensional tryptic phosphopeptide maps for the mutant and wild-type proteins (36); furthermore, a phosphorylated synthetic version of the wild-type peptide was resolved from the labelled tryptic fragments (data not shown). We conclude that Thr-52 is not a major phosphorylation site and that the mutant phenotype is probably not due to alteration of the phosphorylation state of the STE5 product. However, we cannot rule out the possibility that minor or very labile phosphorylation events are responsible for the phenotype.

The phenotype of the STES $5^{\text {Hyp }}$ alleles is in some respects similar to that of the overproduced $S T E 5^{+}$gene. Both the $S T E 5^{\text {Hyp }}$ alleles and multiple copies of the $S T E 5^{+}$gene increase the rate of transcription from a pheromone-inducible promoter, and both suppress the sterility phenotype of the ste 2 deletion mutant and the temperature-sensitive ste4-3 mutant. However, the STE $5^{H y p}$ alleles differ from the $S T E 5^{+}$ allele in their ability to bypass deletions of the STE4 and STE18 genes. In both the suppressor analysis and the transcriptional assay, multiple copies of the $S T E 5^{+}$gene had no effect in ste 4 or ste 18 deletion cells, while $S T E 5^{\text {Hyp }}$-2 increased mating and transcriptional activity 100 -fold. Thus, the $S T E 5^{H y p}$ product, unlike the $S T E 5^{+}$product, can act in the absence of $G_{\beta \gamma}$ complex. Furthermore, the hyperactivity is not due to increased steady-state levels of STE5 gene product, as shown by comparing immunoblots that were prepared from extracts of cells expressing the $S T E 5^{+}$or $S T E 5^{H y p}$ alleles. In fact, for cells that contain an intact signal transduction pathway, the level of mutant protein was much lower than that of the wild type. This low level of mutant protein was apparently not due to mutations which inhibited replication or segregation of the plasmid, because plasmid pDJ179 contains only a single base pair change in the STE5 coding region. Furthermore, the level of STE5 protein produced from pDJ179 was the same as that of the wild type when both were expressed in a ste12 strain, in which the growth rate was unaffected by the $S T E 5^{H y p}$ mutation. The observed low level of $S T E 5^{H y p_{-}} 2$ product in the $S T E 12^{+}$ strain may result either from a growth advantage of cells that contain fewer copies of the plasmid or from a STE12dependent feedback mechanism that reduces the levels of STE5 product.

The steps of the pheromone response pathway are defined genetically by null alleles of the $S T E$ genes that block signal transduction. The ability of the STE $5^{\text {Hyp }}$ alleles to bypass these blocks was monitored by the suppression of sterility and the acquisition of pheromone-independent transcription from a pheromone-inducible promoter. Our results indicated that the STE5 product acts after the $\alpha$-factor receptor (encoded by the STE2 gene) and the $\mathrm{G}_{\beta \gamma}$ complex (encoded by STE4 and STE18). The work of others $(8,21,29,76)$ indicates that the $S T E 5$ product functions before four protein kinases (encoded by $S T E 7, S T E 11, K S S 1$, and FUS3) and a transcription factor (encoded by STE12). Our results are consistent with these findings; however, we are unable to distinguish between the possibilities that the STE5 product functions before or functions at the same step as the STE7, $-11,-12$, or $F U S 3$ product. Other published work $(6,23)$ indicates that simple overexpression of STE5 can partially suppress certain fus 3 single mutants; this result is not inconsistent with the proposed order, since STE5 overex- pression failed to bypass the defect in pheromone-unresponsive fus $3 \mathrm{kss} 1$ double mutants. Thus, the STE5 product acts as close to the $G_{\beta \gamma}$ complex as any protein that has been reported to participate in the transduction of the pheromoneinduced signal from the $G$ protein to the nucleus, and it is therefore a candidate for the direct transducer of the $G$ protein signal. The STE20 gene product, which is predicted to encode a protein kinase, is also a possible direct transducer of the $G$ protein signal. Mutations in this gene lead to a block in the pheromone response pathway that can be suppressed by $S T E 5^{H y p_{-1}}$ and $S T E 5^{H y p_{-} 2}$ but not by overproduction of the $S T E 4^{+}$product (53); these results suggest that the STE20 gene product acts at or after the $G_{\beta \gamma}$ step and before the STE5 gene product. Although a constitutive STE20 mutant has been described (68), the relationship of this mutant to the $G$ protein remains unresolved, since the authors report that it is unclear whether the phenotype is specific to the pheromone response pathway.

Several lines of evidence indicate that the pheromone response pathway is partially activated at a low basal level in the absence of pheromones. As depicted in Table 4, the basal activity of the pheromone-inducible promoter that remains in the various ste null mutants correlates with the position of the defective step in the response pathway. The earlier blocks in the pathway result in higher levels of basal signal, suggesting that spontaneous signals ("noise") arising at the earlier steps in the pathway are propagated through the later steps. The fact that the ste 5 null mutant showed a higher level of basal signal than the ste7, ste11, or fus3 kss 1 mutant provides suggestive evidence that the STE5 product acts before the protein kinase products of these genes in the pathway. An early source of noise in the pathway may result from a small degree of spontaneous disassociation of the $G$ protein subunits, causing partial activation of the response pathway in the absence of pheromone (82). Such a model is consistent with the observation that plasmids containing STE $5^{H y p}$ are more stable and cause lower levels of pheromone-inducible transcription in the ste 4 and ste 18 mutants, even though the $G_{\beta}$ and $G_{\gamma}$ products appear to act upstream. The $S T E 5^{\text {Hyp }}$ product, while partially independent of this upstream signal in that it leads to partial restoration of fertility and basal transcription in the ste 4 and ste 18 mutants, is activated further by the small amount of free $G_{\beta \gamma}$ in wild-type cells. In a sense, the $S T E 5^{H y p}$ product amplifies the noise that is generated at the earlier step in the pathway.

The $S S T 2$ gene product regulates the pheromone response pathway and allows cells to resume the division cycle after persistent exposure to pheromone $(3,12,18)$. Our results indicate that this adaptive response promoted by the $S S T 2$ product is required for the growth of strains containing an activated $S T E 5$ gene product. Although the precise action of the $S S T 2$ product is presently unknown, a number of observations are consistent with the notion that it regulates $G$ protein function. (i) The sst 2 mutation can suppress conditionally unresponsive alleles of STE4 (ste 4-3, ste4-5, and ste4-6) in combination with either ros $1,-2$, or -3 mutations, but it has no effect on the ste5-3 allele, suggesting that the $S S T 2$ product may affect the $G$ protein but not the STE 5 gene product (47). (ii) The inability of cells to recover from the growth-inhibitory effects of gpal null mutations (even though the SST2 gene is fully induced) is consistent with a role for the $G P A 1$ product in adaptation $(3,20)$. (iii) The requirement of the $S S T 2$ gene product for recovery from $S T E 4^{H p l}$-induced cell cycle arrest suggests that the $S S T 2$ product negatively regulates the $G$ protein or a subsequent 
step in the pathway (3). (iv) Here we show that the sst2 mutation enhances the growth defect of the STE5 $5^{\text {Hy }}$-1 mutant and that this effect of $s s t 2$ on STE $5^{\text {Hyp }}$ is blocked in strains harboring a deletion of the STE4 gene. This result suggests that the $S S T 2$ product acts before the G protein or at the same step. However, other interpretations are possible. Since we also show that ste 4 mutations reduce the severity of the defects in the STE5 ${ }^{H y p}$ mutants, the possibility remains that the $S T E 4$ product acts before the $S S T 2$ product and that the activity of the $S T E 4$ product is necessary to enhance the phenotype of the $S T E 5^{\text {Hyp }}$ product enough to allow us to detect the effect of the sst 2 mutation.

\section{ACKNOWLEDGMENTS}

We thank M. Whiteway, D. Higgins, K. Tatchell, B. Errede, G. Cole, S. Reed, D. Ma, and E. Elion for providing strains and plasmids and $\mathrm{E}$. Leberer for providing results prior to publication.

D. Blinder and M. S. Hasson contributed equally to this investigation.

This work was supported by Public Health Service research grants GM34719 (to D.D.J.) and GM21841 (to J.T.) from the National Institute of General Medical Sciences.

\section{REFERENCES}

1. Alani, E., L. Cao, and N. Kleckner. 1987. A method for gene disruption that allows repeated use of URA3 selection in the construction of multiply disrupted yeast strains. Genetics 116: 541-545.

2. Blinder, D., S. Bouvier, and D. D. Jenness. 1989. Constitutive mutants in the yeast pheromone response: ordered function of the gene products. Cell 56:479-486.

3. Blinder, D., and D. D. Jenness. 1989. Regulation of postreceptor signaling in the pheromone response pathway of Saccharomyces cerevisiae. Mol. Cell. Biol. 9:3720-3726.

4. Blumer, K. J., J. E. Reneke, and J. Thorner. 1988. The STE2 gene product is the ligand-binding component of the $\alpha$-factor receptor of Saccharomyces cerevisiae. J. Biol. Chem. 263: 10836-10842.

5. Boeke, J. D., F. LaCroute, and G. R. Fink. 1984. A positive selection for mutants lacking orotidine-5'-phosphate decarboxylase activity in yeast: 5-fluoro-orotic acid resistance. Mol. Gen. Genet. 197:345-346.

6. Brill, J. A. 1993. Ph.D. thesis. Massachusetts Institute of Technology, Cambridge.

7. Burkholder, A. C., and L. H. Hartwell. 1985. The yeast $\alpha$-factor receptor: structural properties deduced from the sequence of the STE2 gene. Nucleic Acids Res. 13:8463-8475.

8. Cairns, B. R., S. W. Ramer, and R. D. Kornberg. 1992. Order of action of components in the yeast pheromone response pathway revealed with a dominant allele of the STE11 kinase and the multiple phosphorylation of the STE7 kinase. Genes Dev. 6:1305-1318.

9. Cartwight, C. P., and D. J. Tipper. 1991. In vivo topological analysis of Ste2, a plasma membrane protein, by using $\beta$-lactamase gene fusions. Mol. Cell. Biol. 11:2620-2628.

10. Chaleff, D. T., and K. Tatchell. 1985. Molecular cloning and characterization of the STE7 and STE11 genes of Saccharomyces cerevisiae. Mol. Cell. Biol. 5:1878-1886.

11. Chan, R. K., and C. A. Otte. 1982. Isolation and genetic analysis of Saccharomyces cerevisiae mutants supersensitive to G1 arrest by a-factor and $\alpha$-factor pheromones. Mol. Cell. Biol. 2:11-20.

12. Chan, R. K., and C. A. Otte. 1982. Physiological characterization of Saccharomyces cerevisiae mutants supersensitive to G1 arrest by a-factor and $\alpha$-factor pheromones. Mol. Cell. Biol. 2:21-29.

13. Clark, K. L., N. G. Davis, D. K. Wiest, J.-J. Hwang, and G. F. Sprague, Jr. 1988. Response of yeast $\alpha$ cells to a-factor pheromone: topology of the receptor and identification of a compo- nent of the response pathway. Cold Spring Harbor Symp. Quant. Biol 53:611-620.

14. Clark, K. L., and G. F. Sprague, Jr. 1989. Yeast pheromone response pathway: characterization of a suppressor that restores mating to receptorless mutants. Mol. Cell. Biol. 9:26822694.

15. Cole, M. G., E. D. Stone, and S. I. Reed. 1990 . Stoichiometry of G protein subunits affects the Saccharomyces cerevisiae mating pheromone signal transduction pathway. Mol. Cell. Biol. 10: 510-517.

16. Courchesne, W. E., R. Kunisawa, and J. Thorner. 1989. A putative protein kinase overcomes pheromone-induced arrest of cell cycling in S. cerevisiae. Cell 58:1107-1119.

17. Curran, B. P. G., and B. L. A. Carter. 1986. $\alpha$-factor enhancement of hybrid formation by protoplast fusion in Saccharomyces cerevisiae. Curr. Genet. 10:943-945.

18. Dietzel, C., and J. Kurjan. 1987. Pheromone regulation and sequence of the Saccharomyces cerevisiae SST2 gene: a model for desensitization to pheromone. Mol. Cell. Biol. 7:416-427.

19. Dietzel, C., and J. Kurjan. 1987. The yeast SCG1 gene: a $\mathrm{G} \alpha$-like protein implicated in the a- and $\alpha$-factor response pathway. Cell 50:1001-1010.

20. Dohlman, H. G., and J. Thorner. Unpublished data.

21. Dolan, J. W., and S. Fields. 1990. Overproduction of the yeast STE12 protein leads to constitutive transcriptional induction. Genes Dev. 4:492-502.

22. Dolan, J. W., C. Kirkman, and S. Fields. 1989. The yeast STE12 protein binds to the DNA sequence mediating pheromone induction. Proc. Natl. Acad. Sci. USA 86:5703-5707.

23. Elion, E. A., J. A. Brill, and G. R. Fink. 1991. Functional redundancy in the yeast cell cycle: FUS3 and Kss1 have both overlapping and unique functions. Cold Spring Harbor Symp. Quant. Biol. 56:41-49.

24. Elion, E. A., J. A. Brill, and G. R. Fink. 1991. FUS3 represses $C L N 1$ and $C L N 2$ and in concert with $K S S 1$ promotes signal transduction. Proc. Natl. Acad. Sci. USA 88:9392-9396.

25. Elion, E. A., P. L. Grisafi, and G. R. Fink. 1990. FUS3 encodes a $C D C 2^{+} / C D C 28$-related kinase required for the transition from mitosis into conjugation. Cell 60:649-664.

26. Errede, B., and G. Ammerer. 1989. STE12, a protein involved in cell-type-specific transcription in yeast, is part of protein-DNA complexes. Genes Dev. 3:1349-1361

27. Fields, S., and I. Herskowitz. 1987. Regulation by the yeas mating-type locus of STE12, a gene required for cell-typespecific expression. Mol. Cell. Biol. 7:3818-3821.

28. Freedman, R., J. Schultz, and J. Thorner. 1985. Molecular analysis of the STE5 gene product, a haploid-specific function required for pheromone-induced cell-cycle arrest. J. Cell. Biochem. 9C(Suppl.):106.

29. Gartner, A., K. Nasmyth, and G. Ammerer. 1992. Signal transduction in Saccharomyces cerevisiae requires tyrosine and threonine phosphorylation of FUS3 and KSS1. Genes Dev. 6:1280-1292.

30. Hagen, D. C., G. MacCaffrey, and G. F. Sprague, Jr. 1991. Pheromone response elements (PREs) are necessary and sufficient for basal and pheromone-induced transcription of the FUS1 gene of Saccharomyces cerevisiae. Mol. Cell. Biol. 11:2952-2961.

31. Hagen, D. C., G. McCaffirey, and G. F. Sprague, Jr. 1986. Evidence the yeast STE3 gene encodes a receptor for the peptide pheromone a factor: gene sequence and implications for the structure of the presumed receptor. Proc. Natl. Acad. Sci. USA 83:1418-1422.

32. Hagen, D. C., and G. F. Sprague, Jr. 1984. Induction of the yeast $\alpha$-specific $S T E 3$ gene by the peptide pheromone a-factor. J. Mol. Biol. 178:835-852.

33. Hartwell, L. H. 1967. Macromolecular synthesis in temperaturesensitive mutants of yeast. J. Bacteriol. 93:1662-1670.

34. Hartwell, L. H. 1973. Synchronization of yeast haploid cell cycles, a prelude to conjugation. Exp. Cell. Res. 76:111-117.

35. Hartwell, L. H. 1980. Mutants of Saccharomyces cerevisiae unresponsive to cell division control by polypeptide mating hormone. J. Cell Biol. 85:811-822. 
36. Hasson, M. S. 1992. Ph.D. thesis. University of California, Berkeley.

37. Hasson, M. S., R. Freedman, J. Schultz, E. Barfod, D. D. Jenness, and J. Thorner. Unpublished data.

38. Hereford, L. M., and L. H. Hartwell. 1974. Sequential gene function in the initiation of Saccharomyces cerevisiae DNA synthesis. J. Mol. Biol. 84:445-461.

39. Hill, E. J., M. A. Myers, T. J. Koerner, and A. Tzagolofi. 1986. Yeast/E. coli shuttle vectors with unique restriction sites. Yeast 2:163-167.

40. Hoffman, C. S., and F. Winston. 1987. A ten-minute DNA preparation from yeast efficiently releases autonomous plasmids for transformation of Escherichia coli. Gene 8:822-827.

41. Ito, H., A. Fukada, A. Mirata, and A. Kimura. 1983. Transformation of intact yeast cells treated with alkali cations. J. Bacteriol. 153:163-168.

42. Jackson, C. L., and L. H. Hartwell. 1990. Courtship in S. cerevisiae: both cell types choose mating partners by responding to the strongest pheromone signal. Cell 63:1039-1051.

43. Jackson, C. L., J. B. Konopka, and L. H. Hartwell. 1991. S. cerevisiae $\alpha$ pheromone receptors activate a novel signal transduction pathway for mating partner discrimination. Cell 67:389-402.

44. Jahng, K.-Y., J. Ferguson, and S. I. Reed. 1988. Mutations in a gene encoding the a subunit of Saccharomyces cerevisiae G protein indicate a role in mating pheromone signaling. Mol. Cell. Biol. 8:2484-2493.

45. Jarvik, J., and D. Botstein. 1973. A genetic method for determining the order of events in a biological pathway. Proc. Natl. Acad. Sci. USA 70:2046-2050.

46. Jenness, D. D., A. C. Burkholder, and L. H. Hartwell. 1983. Binding of $\alpha$-factor pheromone to yeast a cells: chemical and genetic evidence for an $\alpha$-factor receptor. Cell 35:521-529.

47. Jenness, D. D., B. S. Goldman, and L. H. Hartwell. 1987. Saccharomyces cerevisiae mutants unresponsive to $\alpha$-factor pheromone: $\alpha$-factor binding and extragenic suppression. Mol. Cell. Biol. 7:1311-1319.

48. Konopka, J. B., D. D. Jenness, and L. H. Hartwell. 1988. The $C$-terminus of the $S$. cerevisiae $\alpha$-pheromone receptor mediates an adaptive response to pheromone. Cell 54:609-620.

49. Koshland, D., J. C. Kent, and L. H. Hartwell. 1985. Genetic analysis of the mitotic transmission of minichromosomes. Cell 40:393-403.

50. Kronstad, J. W., J. A. Holly, and V. L. MacKay. 1987. A yeast operator overlaps an upstream activation site. Cell 50:369-377.

51. Kuchler, K., H. G. Dohlman, and J. Thorner. 1993. The a-factor transporter (STE6 gene product) and cell polarity in the yeast Saccharomyces cerevisiae. J. Cell Biol. 120:1203-1215.

52. Laemmli, U. K. 1970. Cleavage of structural proteins during the assembly of the head of bacteriophage T4. Nature (London) 227:680-685.

53. Leberer, E., D. Dignard, D. Harcus, D. Y. Thomas, and M. Whiteway. 1992. The protein kinase homologue Ste20p is required to link the yeast pheromone response G-protein $\beta \gamma$ subunits to downstream signalling components. EMBO J. 11: 4815-4824.

54. Lipke, P. N., D. Wojciechowicz, and J. Kurjan. 1989. AGol is the structural gene for the Saccharomyces cerevisiae $\alpha$-agglutinin, a cell surface glycoprotein involved in cell-cell interactions during mating. Mol. Cell. Biol. 9:3155-3165.

55. Ma, D., J. G. Cook, and J. Thorner. Submitted for publication.

56. MacKay, V. L. 1983. Cloning of yeast STE genes in $2 \mu \mathrm{m}$ vectors. Methods Enzymol. 101:325-343.

57. Mackay, V. L., and T. R. Manney. 1974. Mutations affecting sexual conjugation and related processes in Saccharomyces cerevisiae. I. Isolation and phenotypic characterization of nonmating mutants. Genetics 76:255-271.

58. Marsh, L., and I. Herskowitz. 1988. STE2 protein of Saccharomyces kluveri is a member of the rhodopsin/ $\beta$-adrenergic receptor family and is responsible for recognition of the peptide ligand $\alpha$ factor. Proc. Natl. Acad. Sci. USA 85:3855-3859.

59. Marsh, L., A. M. Neiman, and I. Herskowitz. 1991. Signal transduction during pheromone response in yeast. Annu. Rev. Cell Biol. 7:699-728.
60. McCaffrey, G., F. Clay, K. Kelsay, and G. F. Sprague, Jr. 1987. Identification and regulation of a gene required for cell fusion during mating of the yeast Saccharomyces cerevisiae. Mol. Cell. Biol. 7:2680-2690.

61. Miyajima, I., M. Nakafuku, N. Nakayama, C. Brenner, A. Miyajima, K. Kaibuchi, K. Arai, Y. Kaziro, and K. Matsumoto. 1987. GPA1, a haploid-specific essential gene, encodes a yeast homolog of mammalian $G$ protein which may be involved in mating factor signal transduction. Cell 50:1011-1019.

62. Mortimer, R. K., and D. C. Hawthorne. 1969. Yeast genetics, p. 385-460. In A. H. Rose and J. S. Harrison (ed.), The yeasts. Academic Press, New York.

63. Mukai, Y., S. Harashima, and Y. Oshima. 1993. Function of the Ste signal transduction pathway for mating pheromones sustains MATal transcription in Saccharomyces cerevisiae. Mol. Cell. Biol. 13:2050-2060.

64. Nakayama, N., Y. Kaziro, K. Arai, and K. Matsumoto. 1988. Role of STE genes in the mating factor signalling pathway mediated by GPA1 in Saccharomyces cerevisiae. Mol. Cell. Biol. 8:3777-3783.

65. Nakayama, N., A. Miyajima, and K. Arai. 1985. Nucleotide sequences of STE2 and STE3, cell type-specific sterile genes from Saccharomyces cerevisiae. EMBO J. 7:4335-4346.

66. Nomoto, L., N. Nakayama, K. Arai, and K. Matsumoto. 1990. Regulation of the pheromone response pathway by $G$ protein subunits. EMBO J. 9:691-696.

67. Perlman, R., D. Yablonski, G. Simchen, and A. Levitzki. 1993. Cloning of the STE5 gene of Saccharomyces cerevisiae as a suppressor of the mating defect of the $c d c 25$ temperaturesensitive mutants. Proc. Natl. Acad. Sci. USA 90:5474-5478.

68. Ramer, S. W., and R. W. Davis. 1993. A dominant truncation allele identifies a gene, STE20, that encodes a putative protein kinase necessary for mating in Saccharomyces cerevisiae. Proc. Natl. Acad. Sci. USA 90:452-456.

69. Rhodes, N., I. Connell, and B. Errede. 1990. STE11 is a protein kinase required for cell-type-specific transcription and signal transduction in yeast. Genes Dev. 4:1862-1874.

70. Rine, J., and I. Herskowitz. 1987. Four genes responsible for a position effect on expression from $H M L$ and $H M R$ in Saccharomyces cerevisiae. Genetics 116:9-22.

71. Rose, M. D., and G. R. Fink. 1987. KAR1, a gene required for function of both intranuclear and extranuclear microtubules in yeast. Cell 48:1047-1060.

72. Rose, M. D., B. Price, and G. R. Fink. 1986. Saccharomyces cerevisiae fusion requires prior activation by alpha factor. Mol. Cell. Biol. 6:3490-3497.

73. Sambrook, J., E. F. Fritsch, and T. Maniatis. 1989. Molecular cloning: a laboratory manual, 2nd ed. Cold Spring Harbor Laboratory, Cold Spring Harbor, N.Y.

74. Sikorski, R. S., and P. Hieter. 1989. A system of shuttle vectors and yeast host strains designed for efficient manipulation of DNA in Saccharomyces cerevisiae. Genetics 122:19-27.

75. Sprague, G. F., Jr., and J. Thorner. 1992. Pheromone response and signal transduction during the mating process of Saccharomyces cerevisiae, p. 657-744. In J. R. Broach, J. R. Pringle, and E. W. Jones (ed.), The molecular and cellular biology of the yeast Saccharomyces. Cold Spring Harbor Laboratory Press, Cold Spring Harbor, N.Y.

76. Stevenson, B. J., N. Rhodes, B. Errede, and G. F. Sprague. 1992. Constitutive mutants of the protein kinase STE11 activate the yeast pheromone response pathway in the absence of the $G$ protein. Genes Dev. 6:1293-1304.

77. Stone, D. E., G. M. Cole, M. D. Lopes, M. Goebl, and S. I. Reed. 1991. N-myristoylation is required for function of the pheromone-responsive $\mathrm{G} \alpha$ protein of yeast-conditional activation of the pheromone response by a temperature-sensitive $\mathrm{N}$-myristoyl transferase. Genes Dev. 5:1969-1981.

78. Teague, M. A., D. T. Chalef, and B. Errede. 1986. Nucleotide sequence of the yeast regulatory gene STE7 predicts a protein homologous to protein kinases. Proc. Natl. Acad. Sci. USA 83:7371-7375.

79. Trueheart, J., J. D. Boeke, and G. R. Fink. 1987. Two genes required for cell fusion during yeast conjugation: evidence for a 
pheromone-induced surface protein. Mol. Cell. Biol. 7:2316-2328.

80. Van Arsdell, S., F. Gimble, E. Lo, and J. Thorner. Unpublished data.

81. Van Arsdell, S. W., G. L. Stetler, and J. Thorner. 1987. The yeast repeated element sigma contains a hormone-inducible promoter. Mol. Cell. Biol. 7:749-759.

82. Whiteway, M., L. Hougan, D. Dignard, D. Y. Thomas, L. Bell,
G. C. Saari, F. J. Grant, P. O'Hara, and V. L. MacKay. 1989. The STE4 and STE18 genes of yeast encode potential $\beta$ and $\gamma$ subunits of the mating factor receptor-coupled $G$ protein. Cell 56:467-477.

83. Whiteway, M., L. Hougan, and D. Y. Thomas. 1990. Overexpression of the STE4 gene leads to mating response in haploid Saccharomyces cerevisiae. Mol. Cell. Biol. 10:217-222. 